\title{
Regional geochemical comparisons from the Lower Palaeozoic, Southern Uplands - Down-Longford terrane in Northern Ireland and Scotland
}

\author{
N. Breward ${ }^{1}$, P. Stone ${ }^{2}$, D. Flight ${ }^{1}$ and T. B. Anderson ${ }^{3}$
}

1. British Geological Survey, Keyworth, Nottingham, NG12 5GG, UK (email: nbr@bgs.ac.uk; dmaf@bgs.ac.uk )

2. British Geological Survey, Murchison House, West Mains Road, Edinburgh, EH9 3LA, UK (e-mail: psto@bgs.ac.uk )

3. c/o Geological Survey of Northern Ireland, Colby House, Stranmillis Court, Belfast BT9 5BF email: tbernardanderson@hotmail.com

\section{Synopsis}

Newly-acquired regional geochemical data for the Down-Armagh (Northern Ireland) sector of the Southern Uplands - Down-Longford terrane are assessed by comparison with the equivalent dataset for southern Scotland. Despite the much thicker glacigenic cover to the Down-Armagh bedrock, the principal geochemical lineaments identified in the Southern Uplands are still apparent. Patterns of element distribution emphasise the continuity of structure and stratigraphy between the two regions, with $\mathrm{Cr}, \mathrm{Zr}$, Sr, $\mathrm{Rb}, \mathrm{Ba}$ and $\mathrm{Ca}(\mathrm{as} \mathrm{CaO}$ ) proving particularly instructive. Much of the Down-Armagh outcrop consists of Llandovery strata from the Gala and Hawick Groups, so it is this part of the terrane that is most closely considered. Though continuity is clear, there is a suggestion of additional structural imbrication in Down-Armagh, whilst variability in the defining element ratios suggests along-strike compositional changes in the turbidite sandstones. These changes may be controlled by lithostratigrapical variation in sedimentary provenance, or may be influenced by the dominant palaeocurrent flow towards the south west, which has resulted in a broadly more distal and mature Llandovery turbidite lithofacies in Down-Armagh than in the Southern Uplands.

\section{Introduction}

The paratectonic zone of the British and Irish Caledonides includes the Southern Uplands - Down-Longford (SUDL) terrane (Fig. 1), an imbricate thrust belt of turbidite-facies strata that developed from the late Ordovician to the mid-Silurian along the Laurentian margin of the Iapetus Ocean. Internally, the terrane comprises about twenty fault-defined tracts elongated NE-SW parallel to strike, in most of which the strata are steeply inclined and become younger towards the NW; yet the minimum 
age of the graptolites in each individual tract generally becomes incrementally younger towards the SE (Floyd 2001 and references therein). The Southern Upland Fault forms the NW margin of the terrane, which forms the southernmost tectonic unit of the Caledonides in Scotland and Ireland and lies immediately to the north of the Iapetus Suture (Fig. 1). The minimum age of the component tracts ranges from Caradoc (Late Ordovician) in the NW adjacent to the Southern Upland Fault, to Wenlock (Mid-Silurian) in the SE adjacent to the Iapetus Suture.

The Southern Uplands regional geochemical dataset forms part of the British Geological Survey’s G-BASE (Geochemical Baseline Survey of the Environment) project, a comprehensive overview of the distribution of elements in the surface environment of Britain derived from the analysis of the $<150$ micron stream sediment fraction, systematically collected at a density of approximately one sample per 1.5 $\mathrm{km}^{2}$. Data for about 35 elements are available, with the methods of collection, analysis and data processing detailed in an illustrated geochemical atlas (British Geological Survey 1993). A similar dataset has been recently acquired for Northern Ireland, as part of the Tellus Project of the Geological Survey of Northern Ireland, which allows a comparison of results from the two parts of the SUDL terrane as an independent means of correlation and comparison along a combined strike length in excess of $350 \mathrm{~km}$. In this paper we demonstrate similar, but not identical, patterns of element distribution and discuss their implications for the regional geology.

The SUDL terrane has an outcrop area of about 10,000 $\mathrm{km}^{2}$ across southern Scotland and about 6,000 $\mathrm{km}^{2}$ in Ireland (Fig. 1), where it extends across much of Counties Down and Armagh in Northern Ireland (c. 3,500 $\mathrm{km}^{2}$ ) and thence into the Irish Republic, mostly within Counties Louth, Monaghan, Cavan and Longford (c. 2,500 $\mathrm{km}^{2}$ ). This paper is concerned only with that part of the terrane in Northern Ireland (hereafter Down-Armagh), for which the new geochemical data is available.

In Ireland the stratigraphical range at outcrop is slightly more restricted than that seen in Scotland. The north-western terrane boundary, the continuation of the Southern Upland Fault, is overstepped by Carboniferous and younger strata so that the outcrop area of Ordovician tracts is limited and the equivalents to the northernmost tracts of the Southern Uplands, if present, are concealed (rather more Ordovician strata crops 
out in the Irish Republic). The south-east limit of the terrane lies within the Irish Republic, where Wenlock strata have been reported from County Louth (Vaughan \& Johnston, 1992); elsewhere the Wenlock and the youngest of the Llandovery tracts are unconformably overlain by Carboniferous strata. Thus the outcrop of the SUDL terrane in Northern Ireland largely comprises Llandovery tracts of the Gala and Hawick groups. A more detailed correlation has been established (Barnes et al. 1987) for the tracts forming those groups on either side of the North Channel: the Rhins of Galloway (Scotland) and the Ards Peninsula (Northern Ireland). From this it is apparent that the Gala Group outcrop has a significantly greater cross-strike width in Northern Ireland (c. 27 km) than in south-west Scotland (c. 16 km).

Despite the geological similarities between the Scottish and Irish sectors of the SUDL terrane, there are marked topographical differences strongly influenced by contrasting histories of glaciation. In Scotland, the Southern Uplands region is a range of moorland hills with summit plateaux, rising to well over 300 m OD in places, mostly either formed in exposed bedrock or covered by only a thin veneer of peat and glacial deposits. Fast-flowing streams draining the high ground commonly cut through the flanking glacial deposits to expose bedrock. In contrast, the SUDL terrane in Northern Ireland forms largely low-lying agricultural land much of which lies below $100 \mathrm{~m}$ OD. Natural exposure is uncommon and the gently-flowing streams less regularly cut down to bedrock through the thick surface layer of drumlinised till; individual drumlins rise from 5 to $50 \mathrm{~m}$. This difference will inevitably affect the stream sediment compositions from the two regions since virtually all of the Irish sediment must be derived from the glacigenic cover, whereas a high proportion of the Southern Uplands sediment could be eroded directly from bedrock.

\section{An outline of the geological setting}

The structural geometry of the SUDL terrane developed within an accretionary thrust complex at the Laurentian continental margin during northward subduction of the Iapetus Ocean (Leggett et al. 1979; Anderson 2001; Stone \& Merriman 2004 and references therein). The sequential incorporation of tectonic tracts into an active thrust system means that the first deformation was diachronous, older in the north than in the south (Barnes et al. 1989), and the structural profiles can vary along strike 
(Rushton et al. 1996). Each tract ideally comprises a very thin (generally $<150 \mathrm{~m}$ ) black shale sequence (the Moffat Shale Group) overlain by a very much thicker (up to about $2000 \mathrm{~m}$ ) sandstone succession. The Moffat Shale Group (MSG) may span a range of late Ordovician to Silurian graptolite biozones, the upper limit becoming younger southward, but it is rare for the sandstone succession to contain strata spanning more than one biozone. Each biozone represents an interval of about 1.5 million years in the late Ordovician, reducing to nearer 0.5 million years by the midSilurian (Hughes 1995). The tract relationships are the critical evidence for the imbricate thrust geometry.

Whilst much of the detailed work on the SUDL terrane has been in the Scottish sector, its application to the Northern Ireland sector is well established. In regional terms (Fig. 1), the northern tracts of Caradoc and Ashgill (Upper Ordovician) age comprise the Leadhills Supergroup (Floyd 1996) for which the Orlock Bridge Fault (Anderson \& Oliver 1986) forms the southern margin. This zone is also known as the Northern Belt, following Peach \& Horne (1899); though originally applied in southern Scotland the term is also in common usage for the Ordovician rocks of the SUDL terrane in Ireland. Southwards from the Orlock Bridge Fault in south-west Scotland, and as far as the Balmae Burn Fault, a series of Llandovery (Lower Silurian) tracts forms the Gala and Hawick Groups. These two groups are separated from each other by the Laurieston Fault in Scotland, the equivalent structure in Northern Ireland being known as the Cloghy Fault (Figure 1). Following Peach and Horne (1899) the whole Llandovery zone, together with its MSG Ordovician inliers, is also known as the Central Belt throughout the SUDL terrane. South of the Balmae Burn Fault in Scotland, the Riccarton Group comprises Wenlock (Middle Silurian) tracts and is otherwise known as the Southern Belt (Peach \& Horne 1899); there is no equivalent at outcrop in Northern Ireland though Wenlock strata occur to the south in the Irish Republic (Vaughan \& Johnston, 1992).

The Central Belt in Northern Ireland represents a far greater proportion of the SUDL terrane than it does in south-west Scotland. There would appear to be more similarity with the north-east part of the Southern Uplands, where the Ordovician tracts are eliminated by a combination of faulting and an unconformable cover of Carboniferous strata. In tandem with this effect, the Scottish Central Belt widens progressively 
north-eastward through the multiplication of Hawick Group tracts and the introduction of an eastward-broadening structural wedge, bounded by the Moffat Valley and Ettrick Valley (= Laurieston) faults, in which several tracts have compositional characteristics that are in some ways intermediate between the Gala and Hawick groups. On recent British Geological Survey 1:50 000 geological maps (BGS in press) this intermediate zone is designated the Ettrick Group. It overlaps in age with the youngest Gala Group tracts and its effect on the width of the Central Belt is mitigated by a loss of older Gala Group tracts (Rushton et al., 1996). So, for example, in the Rhins of Galloway district the Gala Group has been divided into a series of structural tracts (Stone 1995) numbered in terms of age from 1 (the oldest, most northerly tract) to 8 (the youngest and most southerly tract); tracts 7 and 8 form the southern 25\% of the Gala Group's outcrop width. This contrasts with the situation farther north-east, in the Peebles district, where the repetition of Gala 7 tracts, coupled with the structural elimination of several younger tracts and the introduction of the Ettrick Group, means that strata of Gala 7 age make up a much greater proportion of the outcrop (Rushton et al., 1996). A comparable situation is described from Northern Ireland (Anderson, 2004) where, on the Ards Peninsula, tracts of Gala 7 age (or younger) make up almost $80 \%$ of the Gala Group’s outcrop width. In this respect an important correlative structure is the major strike fault marking the northern limit of Gala 7 tracts: the Drumbreddan Bay Fault in south-west Scotland, the Southern Coalpit Bay Fault in Northern Ireland.

One important difference between the Central Belt strata (and particularly that of the Gala Group) in Scotland and Ireland, is the relatively more distal turbidite facies present in the Irish outcrop relative to the Southern Uplands. A predominant palaeocurrent flow from north-east to south-west is recorded in both areas (e.g. Anderson, 1962; Kelling et al. 1987; Stone, 1995. Transport and sedimentation of the grains now forming the Gala sandstones in Ireland have effected fractionation so that they are compositionally more mature than their stratigraphical equivalents in Scotland. The consequence is a Gala Group sequence in Ireland that, overall, is more thinly bedded and finer grained.

In south-west Scotland the SUDL terrane is intruded by granitic plutons of Early Devonian age. The Loch Doon pluton was emplaced into the Ordovician sector, the 
Cairnsmore of Fleet pluton into the Gala Group, and the Criffel pluton into the Hawick Group. In Northern Ireland, the Early Devonian Newry granitic/granodioritic pluton straddles the Gala-Hawick group boundary, and at its western end has itself been intruded by the Palaeogene Slieve Gullion Central Complex. Other largely granitic, Palaeogene intrusions into the Hawick Group, make up the Mourne Mountains Central Complex.

\section{G-BASE and Tellus Project stream sediment geochemistry}

The British Geological Survey’s G-BASE project is a long-running (and continuing) high-resolution geochemical survey project for the UK landmass (Johnson \& Breward, 2004; Johnson et al., 2005). It developed initially out of a strategic mineral exploration programme for uranium and base metals, mainly utilising stream sediment sampling of low-order drainage. The survey began in northern Scotland in the late 1960s, but has evolved over the years into a much more widely-ranging project with, for example, applications in geological mapping (Stone et al., 2004), environmental baselines and contaminated land (Breward, 2003; Breward, 2007), and urban geochemistry studies (Fordyce et al., 2005), the latter based on soil and stream water sampling in addition to stream sediments. As analytical methods have changed and improved, so the range of elements determined has also increased from about sixteen in the early years (with analyses by Quartz Spectrograph and Atomic Absorption Spectrometry) to about forty-six currently (using X-Ray Fluorescence spectrometry). The detailed G-BASE sampling procedures, which have been widely adopted by international surveys, are given in Johnson (2005). Stream sediment data for about 30 elements were common Sto the surveys carried out in both study areas, and these elements provide the basis for the comparison reported here.

The stream sediment data for the Southern Uplands used in this paper were acquired from part of the area sampled in the late 1970s to early 1980s, with analysis by Direct-reading emission spectrometry. The resultant Geochemical Atlas of Southern Scotland was published in 1993 (British Geological Survey, 1993). The pattern of bedrock tracts, extended NE-SW along strike but relatively narrow in the NW-SE cross-strike direction, is mirrored in the "striped" patterns of element distribution seen in the regional geochemical dataset. Despite glaciation, the stream sediment 
geochemical patterns spatially mimic the outcrop of underlying bedrock lithologies so that, over the sandstone-dominated tracts of the Southern Uplands, contoured regional geochemical data for many elements produce a marked strike-parallel, NE-SW linearity. Although the steepest concentration gradients commonly coincide with tract-bounding faults, different elements show different distribution patterns, a relationship that has been interpreted as reflecting the compositional contrasts between the sandstones contained within the various tracts (Stone et al. 2004 and references therein).

Stream sediments from the western part of Northern Ireland were sampled by GBASE as a special project in 1994-1995 (Flight et al., 1995): subsequently this data was incorporated into the Tellus Project, funded by the Department of Enterprise, Trade and Investment (DETI), Northern Ireland, and sampling completed in 2004 2006. The stream sediments for Northern Ireland were analysed by X-ray fluorescence spectrometry (XRFS). Results were closely monitored for analytical variations arising from the differences in analytical methods, and were crosscalibrated by the use of internal and international standards. The geochemical maps shown here in Figs. 3 to 5 were developed from the Northern Ireland database and created using Inverse Distance Weighting gridding in ESRI ArcView 9.2 ${ }^{\mathrm{TM}}$ GIS software, with the RGB composite maps created using the 'composite bands' function.

\section{Variations in the chemical composition of stream sediment}

The Southern Uplands of Scotland has been established as a classic area for the direct association of regional geochemical element distributions with bedrock stratigraphic outcrop patterns (Stone et al. 1991, 2004, 2006). Across the terrane a markedly linear pattern of element distribution in stream sediment trends NE-SW, mirroring the stratigraphical outcrop pattern in the bedrock (British Geological Survey, 1993). Although northern Britain has been extensively glaciated there is still a high level of spatial coincidence between the outcrop patterns of the different rock types and element distribution in the stream sediment. The clear implication is that stream sediment composition reflects the bedrock geology of the catchment and that glacial 
effects are minimal, whether through the introduction of exotic material or through the transport of locally-derived, glacigenic sediments across geological boundaries.

A series of previous studies have identified several element assemblages as being of value in tracking geologically-controlled changes in sediment composition across the Southern Uplands (Stone et al., 1993, 1999, 2004). Of particular value under appropriate circumstances are the basic-ultrabasic element suite $\mathrm{Cr}-\mathrm{Ni}-\mathrm{Mg}-\mathrm{V}$, the feldspar association Rb-Sr-K-Ba, the resistate mineral association Ti-Y-Zr-La-Cr and the base metal association $\mathrm{Cu}-\mathrm{Pb}-\mathrm{Zn}$-As. Data for these element suites are discussed later. In some cases there is a direct relationship between element abundance in stream sediment and that in the rock from which they are derived. More commonly, there are patterns of enhancement and depletion from rock to sediment that are controlled by the behaviour in the weathering environment of the mineral hosts of any given element (Stone et al., 1997, 2003, 2006).

A number of the above parameters are most applicable to the Ordovician tracts that are only poorly represented in Northern Ireland. In this paper we will focus on the SUDL terrane's Central Belt wherein the Gala and Hawick groups have a substantial outcrop in both Scotland and Northern Ireland. Accordingly, the elements discussed will be those for which the distribution variation is most relevant to a comparison of the Gala and Hawick groups between Scotland and Northern Ireland. The distribution statistics for a selection of elements (Fig. 2) illustrate the compositional character of the stream sediment derived from each of these stratigraphical units.

One of the steepest geochemical gradients in the Scottish data, and one that produces a major regional lineament, is shown by calcium $(\mathrm{CaO})$ which defines a zone of high abundance associated with the Hawick Group contrasting with much lower levels over the Gala Group (British Geological Survey, 1993). The high Ca levels over the Hawick Group directly reflect the carbonate-rich matrix that is a common feature in many of its sandstones. This strong regional lineament also appears in Northern Ireland, again coincident with the boundary between the Hawick and Gala groups (Fig. 3). Although predictable, in that the presence of a carbonate-rich matrix is taken as characteristic of the Hawick Group, the persistence of the resulting lineament encourages the expectation that other, less obvious features of the regional 
geochemistry might also extend from Scotland into Northern Ireland. Across DownArmagh the coincidence of geochemical lineaments with established tectonic structures is most aparent in the north-east of the region. The relationship becomes less well defined to the west of Banbridge and Newry, with a general tendency, increasing westward, for geochemical lineaments to diverge southward from the tract boundary faults as represented on the published geological map (Geological Survey of Northern Ireland 1997). This phenomenon can be explained by the findings of another part of the Tellus programme, a high-resolution, airborne conductivity survey. Results from this (Beamish et al. in press/2010) unequivocally show that the fault lines which were extrapolated from very sparse outcrop data - are misplaced on the map and in fact swing southward into alignment with the geochemical lineaments.

\section{The basic-ultrabasic element association}

From the Scottish distribution statistics (Fig. 2), one of the most dramatic variations is shown by Cr, which is particularly high in association with the Gala Group but also has a large inter-quartile range that suggests internal heterogeneity in the source rocks. There is a marked decrease in Cr from the Gala Group to the Hawick Group such that the median Cr value for the Hawick-derived sediment is simialr to the 25th percentile value for the Gala-derived sediment. An important feature of the Scottish distribution seen clearly in the atlas map (British Geological Survey, 1993) is that within the Gala Group the highest abundance of $\mathrm{Cr}$ is seen in the older tracts, with relatively lower levels associated with the younger, Gala 7 and 8 tracts. This is reflected in Northern Ireland but there, since the Gala 7 tracts form a relatively greater proportion of the group's outcrop, the overall $\mathrm{Cr}$ abundance is lower than in the Southern Uplands, with restriction of the high $\mathrm{Cr}$ abundances to the relatively narrow outcrop of older tracts in the north (Fig. 2). There is a regional lowering of $\mathrm{Cr}$ abundance - high to the north, low to the south - that defines a lineament broadly coincident with the Southern Coalpit Bay Fault, the northern boundary of the Gala 7 tracts (Fig. 4).

One important difference in the Cr distribution between the Scottish and Northern Irish sectors of the SUDL terrane is illustrated by the relationship between $\mathrm{Cr}$ and $\mathrm{Zr}$. In Scotland there is a general association between the high $\mathrm{Cr}$ abundances and 
elevated levels of Zr, which has been taken as indicating their co-derivation from a heavy mineral fraction (Stone et al. 1999, 2003). The role of resistate, heavy minerals is discussed in greater detail below, but the $\mathrm{Cr}-\mathrm{Zr}$ ratio is particularly informative in Down-Armagh. There, relatively high $\mathrm{Zr}$ abundance is seen over the older (northern) Gala Group tracts in coincidence with the high-Cr zones in the north-east and southwest. In contrast, the high levels of $\mathrm{Cr}$ seen to the west of Tanderagee (Fig. 4) are coincident with relatively low $\mathrm{Zr}$ abundance. It is likely that most of the $\mathrm{Cr}$ in this latter area was derived not from the heavy minerals in the Silurian sandstones but from the Palaeogene lavas adjacent to the north, either directly or via glacial transport and reworking from till. An original ferromagnesian mineral host is probable for this Cr.

The distributions of other ultrabasic/basic elements such as Ni and V follow a broadly similar pattern to that shown by $\mathrm{Cr}$, although the differences between the Gala and the Hawick groups are relatively small. The implication is not only of a varying basic component in the sediment influx, but also of a change in character; Ni and V behave similarly throughout and may well have the same basic source, whereas the pattern of Cr distribution in the Southern Uplands Gala Group is strongly dissimilar to that of $\mathrm{Ni}$ and V, and so probably has a distinct source in ultrabasic spinel, a marked increase in which has been noted in pan concentrates collected over Gala Group outcrop (British Geological Survey 1993). A similar situation seems likely in Down-Armagh where Ni shows no clear distinction between the Gala and Hawick groups and the distribution of $\mathrm{V}$ appears to be more influenced by mineralization, with elevated levels seen across the South Armagh Mining District (Arthurs \& Earls, 2004). The absence of a regional trend in $\mathrm{Ni}$, and the slight regional tendency for $\mathrm{V}$ to decrease in abundance southwards, from the Gala Group to the Hawick Group, contradicts the opposite trend seen in Scotland where $\mathrm{Ni}$ and V are both slightly lower over the Gala Group than over the Hawick Group. This absence of any coherent overall pattern in the basic/ultrabasic elements increases the probability that the more consistent $\mathrm{Cr}$ distribution is largely influenced by the resistate mineral assemblage. 


\section{The "feldspar" element association}

A dominant feature of the Scottish stream sediment data from the SUDL terrane (British Geological Survey, 1993; Stone et al., 2004, 2006) is the division of Sr abundances across the Laurieston - Moffat Valley faults: higher to the north over the Gala Group and lower to the south over the Hawick Group (and the "Ettrick Group”, the ambiguous wedge of strata broadening eastwards between the Moffat Valley and Ettrick Valley faults). In Northern Ireland the boundary is less clear-cut, and whilst median values decrease from the Gala Group to the Hawick Group, the latter's interquartile range is the greater (Fig. 2). Lower levels of Sr clearly extend into the southern part of the Gala Group outcrop as currently defined, as far north as the Kircubbin Fault, and lie well to the north of the Ca lineament that coincides with the conventional Gala-Hawick group boundary. In this there is a similarity with the eastern part of the SUDL terrane in Scotland where the Sr and Ca lineaments diverge eastwards, the former following the Moffat Valley Fault and the latter following the Ettrick Valley (= Laurieston) Fault. The cause of the divergence in Scotland is thought to be the introduction of additional structural tracts - with unique characteristics in the composition of their component sandstone - in the eastwardbroadening wedge (Stone et al., 2004) recently defined as the Ettrick Group (British Geological Survey; in press). The similar disassociation seen in Northern Ireland suggests the presence there of comparable low Ca-Sr tectonostratigraphical additions, currently designated the youngest tracts of the Gala Group. The relatively low values for Ca recorded between the Cloghy and Kircubbin faults persist despite the presence there of abundant lamprophyre dykes associated with carbonate veining and replacement. It would seem that the regional geochemical background, as determined by the sandstone country rock, still dominates and effectively masks local variations.

If $\mathrm{Sr}$ distribution in stream sediment is largely controlled by the character of the feldspar in the sandstones from which it was derived, then a comparable but inverse distribution pattern might be expected for $\mathrm{Rb}$. As regards to provenance, $\mathrm{Rb}$ is generally enriched in the potassic feldspars of granites, especially 'evolved' varieties, whereas $\mathrm{Sr}$ is predominantly found at elevated levels in the calcic plagioclase feldspars of diorites and granodiorites, and metamorphic rocks derived from them. Consequently, $\mathrm{Rb}$ concentrations in sediments over the Hawick Group should be 
higher than over the Gala Group. In the regional stream sediment geochemistry, however, the situation is not that clear-cut, as active physiochemical processes are involved in the formation of the stream sediment.

In Scotland, though the anticipated higher Rb abundances are seen over the Hawick Group, they are also present over the southern part of the Gala Group, with a weaklydefined lineament marking a decrease to lower Rb abundance over the northern Gala Group. There is even less variation in Northern Ireland with only a small increase in overall Rb abundance southwards from the Gala Group to the Hawick Group (Fig. 5). One explanation for this apparent contradiction might lie in the tendency for $\mathrm{Rb}$ abundance to increase markedly into stream sediment from its source rock whilst $\mathrm{Sr}$ shows little change for the Gala Group and a slight depletion for the Hawick Group (Stone et al., 2003; 2006).

The $\mathrm{Rb}$ enhancement in the stream sediment may arise either from concentration of detrital K-feldspar grains relative to the less stable plagioclase grains, or from a higher proportion of clay (which can strongly adsorb $\mathrm{Rb}$ ) in the sediment relative to the source rock. The probable increase in the proportion of the stream sediment derived from clay-rich till in Down-Armagh, relative to the situation in the Southern Uplands, may also be a significant factor in the concentration of Rb by sorption .

Across the Southern Uplands, $\mathrm{K}$ (as $\mathrm{K}_{2} \mathrm{O}$ ) distribution in the stream sediment broadly matches that of Rb, being generally higher over the northern Hawick Group and the southern part of the Gala Group than over the northern Gala Group. In Down-Armagh a partially reverse pattern is seen, with lower $\mathrm{K}_{2} \mathrm{O}$ abundance over the Hawick Group and the southern part of the Gala Group than over the northern Gala Group, and with some of the highest $\mathrm{K}$ abundances seen over the southern margin of the Hawick Group outcrop. However, sediment derived from the K-rich Mourne Mountains outcrop is a confounding problem in the latter area, and it would be unwise to draw any firm conclusions related to the Hawick Group geochemistry from this pattern.

Conversely, the results for Ba are very similar in Scotland and Northern Ireland. The Gala Group produces relatively high Ba abundance in stream sediment (especially over its younger tracts) which contrasts markedly with the lower abundances seen 
over both the Ordovician sandstones to the north and the Hawick Group to the south. The comparison holds even though the Gala Group in Northern Ireland comprises a much higher proportion of stratigraphically younger structural tracts than it does in Scotland. Isolated high-Ba anomalies in both Scotland and Northern Ireland may arise from localized mineralisation.

Overall, the results from a comparison of the "feldspar" association elements are ambiguous: Ba has a similar abundance pattern in the Southern Uplands and DownArmagh, Sr less so but still with similarities, Rb shows less variation in DownArmagh than in the Southern Uplands, whilst for $\mathrm{K}_{2} \mathrm{O}$ the abundance pattern is quite different in the two areas, even excluding the area probably affected by the Mourne Mountains granite. The ultimate cause of this contrast is unclear, but it may possibly reflect an original difference, along the length of the terrane, in the detrital feldspar proportions of the Gala and Hawick Group sandstones. This could arise from the presence in Down-Armagh of generally more distal and mature turbidite sandstones relative to those seen in the Southern Uplands, but there does seem to be more stratigraphically-controlled variation in the Hawick Group of Down-Armagh than is seen in the Scottish outcrop.

\section{The "resistate mineral" element association}

Chrome-spinel is an important component of stream sediment across the northern (oldest) tracts of the Gala Group in the Southern Uplands (British Geological Survey 1993) and so probably also in Down-Armagh. As discussed above, the high-Cr anomaly corresponds to the older Gala Group tracts to the north of the Drumbreddan Bay Fault (in Scotland) and the Southern Coalpit Bay Fault (in Northern Ireland). Since this structural zone is considerably narrower in Northern Ireland than in Scotland, the elevated Cr levels in stream sediment are commensurately restricted. In Scotland the high levels of Cr over the northern Gala Group are matched by elevated levels of $\mathrm{Zr}$, suggesting the co-concentration of the heavy minerals spinel and zircon. As discussed previously, the situation in Northern Ireland is more complicated, with some Cr probably derived from the Palaeogene lavas adjacent to the northern Gala Group outcrop in Armagh, and having no local co-enhancement with Zr. Spilitic lavas, mafic lithologies that are potentially a source of elevated Cr levels, also occur 
in the Ordovician tract north of the Orlock Bridge Fault in northern Co. Down (Sharpe, 1970), although the outcrop area is small. The southern Gala Group and the Hawick Group outcrops in both Scotland and Northern Ireland are associated with low to medium levels of $\mathrm{Zr}$ in stream sediment, with no clear tectonostratigraphical correlations.

Other elements probably contributed from the heavy, resistate minerals in the stream sediment are Y (in garnet and epidote), Ti (in rutile, titanite and ilmenite), and La (in monazite). None of these elements shows any well-defined partitioning between the Gala and Hawick groups in Scotland, though there is a weakly defined depletion in $\mathrm{Y}$ over the Gala Group relative to the Hawick Group; a more marked depletion in $\mathrm{Y}$ corresponds to some of the Ordovician tracts. Rather more variation is seen in Northern Ireland where both Y and La abundances are highest over the youngest Gala Group tracts relative to the older Gala Group tracts to the north and the Hawick Group tracts to the south. There are also apparent increases in $\mathrm{Y}$ and La abundances over the southernmost of the Hawick Group tracts, but these may be associated with local ‘extraneous’ sediment derived from the Mourne Mountains granite.

The contrasts between the Southern Uplands and Down-Armagh would suggest that the heavy, resistate mineral content of the Lower Palaeozoic turbidite sandstones is variable along strike. The greatest similarity between Scotland and Northern Ireland is seen in the north of the SUDL terrane, where a combined Cr-Zr elevation anomaly (other than sites adjacent to the Palaeogene lavas) spans the Ordovician tracts and the northern part of the Gala Group, though the Zr enrichment is less clear in Northern Ireland than it is in Scotland. The differences between the Southern Uplands and Down-Armagh then seem to increase southwards into the younger tracts, this being most marked by variations in $\mathrm{Y}$ and $\mathrm{La}$.

\section{The "base metal" element association}

In a regional context, the most prominent features of the Pb-Zn-As distribution (and to a lesser extent that of $\mathrm{Cu}$ ) in southern Scotland stream sediment are the halos of elevated abundance seen surrounding the Loch Doon and Cairnsmore of Fleet granitic plutons. These igneous bodies were both intruded, at about 395-400 Ma, into Gala 
Group strata and the base metal halos that were created stand in marked contrast to the absence of any such feature around the coeval Criffel pluton, which was intruded farther south into Hawick Group strata. Stone et al. (1993) speculated that this was a reflection of original compositional differences between the Gala and Hawick groups, with the halos in stream sediment reflecting halos of remobilized base metal in the thermally metamorphosed Gala Group strata.

In Northern Ireland, the largely granodioritic Newry Igneous Complex was intruded as early as $425 \mathrm{Ma}$ (Meighan et al., 2003) in a position spanning the Gala and Hawick Groups, thus cutting and effectively stitching the Cloghy Fault that divides them. Although sediment sites located directly on the outcrop of the intrusions have been excluded from the dataset used for the Northern Ireland geochemical images to avoid skewing the data distribution, those over the sedimentary strata adjacent to the intrusions have been retained. There is little evidence of an elevated halo in any element's distribution pattern around the intrusion, neither in the Gala Group nor in the Hawick Group (Fig. 6). Farther south and much later, the Palaeogene Mourne Mountains Central Complex was intruded into the Hawick Group; again there is little indication in the stream sediment of a clearly associated halo of remobilized base metals, just a few isolated small Pb-Zn anomalies. This may suggest that the original sediments lacked sufficient element concentrations of the heavy metals suite in readily-mobilised forms to allow significant base-metal enrichment in the granite periphery. Alternatively, the circumstances of granite intrusion may have played a part by controlling the extent of hydrothermal circulation.

The main area of elevated base metal associated with the SUDL terrane in Northern Ireland is coincident with the South Armagh Mining District. The mineralisation there is predominantly $\mathrm{Pb}-\mathrm{Zn}$, with a subsidiary $\mathrm{Au}-\mathrm{Ag}$ component (Chapman et al. 2000). Cadmium and As abundance is also particularly elevated in stream sediment. Although the main South Armagh mining area is somewhat distant from the major structure, the vein trends are thought to have been controlled by stress fields associated with the Orlock Bridge Fault (Arthurs and Earls, 2004). This structure separates the Ordovician from the Silurian tracts across the whole terrane and in Scotland is associated with a shear zone up to several kilometers across (the Moniaive Shear Zone: Phillips et al., 1995). Formation of the shear zone fabric overlapped 
thermal metamorphism in the aureole around the Cairnsmore of Fleet pluton (at ca. $400 \mathrm{Ma}$ ), and so was coeval with the generation of the base metal halo. A temporal association may thus exist between the remobilization of base metal around the granites in SW Scotland and the mineralisation in the South Armagh mining district. However, base metal vein mineralisation in SW Scotland is generally considered a Carboniferous phenomenon (e.g. Pattrick and Russell, 1989), as is that in DownArmagh (Parnell, 1995; Baron and Parnell, 2000; Moles, 2004; Moles et al., 1997).

\section{Conclusions}

The most remarkable feature of the regional geochemical dataset for Down-Armagh is that bedrock features are reflected despite the thick cover of glacigenic deposits which are only rarely cut through by streams. It is inevitable that much of the stream sediment sampled was derived from the glacigenic cover, much of which is likely to have been glacially transported, but bedrock composition is still evidently an important influence on the geochemistry of the stream sediments. Across the Southern Uplands, much more of the stream sediment is likely to have been eroded directly from bedrock, so the coincidence there of steep geochemical gradients with major geological boundaries is to be expected. The persistence of geochemical gradients as those major boundaries cross into Down-Armagh is a powerful demonstration of the value of regional geochemistry as a geological surrogate, even in unpromising circumstances, such as thick glacial drift cover.

In geological terms, the regional geochemical dataset for Down-Armagh shows both similarities and differences to the dataset available for the Southern Uplands. The Down-Armagh outcrop is largely made up of the Llandovery Central Belt, comprising the Gala and Hawick groups, so it is the degree of continuity shown by these two groups from Scotland to Ireland that can be most readily assessed. The principal points of comparison are summarised below:

1. In both Scotland and Northern Ireland the carbonate-rich matrix of the Hawick Group produces a strong lineament in regional $\mathrm{CaO}$ abundance in the stream 
sediment, defined by the steep gradient down to the much lower levels of $\mathrm{CaO}$ seen over the Gala Group.

2. In Northern Ireland a lineament in Sr abundance is defined by the steep gradient between its relatively high levels in stream sediment derived from the Gala Group's northern structural tracts, and the much lower levels seen over the southern Gala Group and the Hawick Group. This situation contrasts with that seen in south-west Scotland, where the $\mathrm{Sr}$ and $\mathrm{CaO}$ lineaments both coincide with the Gala-Hawick boundary, but is similar to the relationship seen farther northeast where the introduction of additional structural tracts (the Ettrick Group) low in both $\mathrm{CaO}$ and $\mathrm{Sr}$ causes their respective lineaments to diverge.

3. Of the possible "feldspar association" elements other than Sr, only Ba shows a distribution in stream sediment in Northern Ireland similar to that seen in Scotland, with Ba abundance consistently elevated over the Gala Group, and particularly so over its younger tracts. Between Scotland and Northern Ireland there are contradictory patterns in the distribution of $\mathrm{Rb}$ and $\mathrm{K}_{2} \mathrm{O}$ that appear to reflect lateral differences in the proportion of feldspar minerals in the sandstones from which the stream sediments were derived, which in turn is a result of variations in provenance and sediment transport and deposition. The turbidite sandstones in Down-Armagh are broadly more distal and mature than their stratigraphical equivalents in the Southern Uplands. A similar explanation might apply to the differences seen in a variety of elements between the central and SW parts of the Southern Uplands (Fig. 2); such trends are worthy of further examination.

4. High levels of $\mathrm{Cr}$ and $\mathrm{Zr}$ in stream sediment have a consistent association with the older structural tracts of the Gala Group, though this is more clearly seen in Scotland. A consistently high level of spinel and zircon in the resistate mineral assemblage of the Gala Group's older sandstones - the source of the stream sediment - seems likely. However, a complication in Northern Ireland is the likely derivation of some $\mathrm{Cr}$ (but not Zr) from adjacent Palaeogene mafic lavas and sills.

5. Differences in the abundance pattern of $\mathrm{Y}$ and La between the stream sediment from Scotland and Northern Ireland suggests that the nature of the heavy, resistate mineral component changes laterally. This probably reflects changes in the 
composition of the sandstones from which the sediment was derived, and again the more distal facies represented in Down-Armagh, being finer-grained and possibly more mature, may be responsible for these differences.

6. The absence from the Northern Ireland stream sediment of a significant base metal halo around the mainly granodioritic pluton of the Newry Igneous Complex contrasts with the strongly developed halos around coeval granites that are similarly intruded into the Gala Group in south-west Scotland. It is not clear whether this reflects original geochemical differences in the Gala Group sandstones or in the intrusion process of the granite.

\section{Acknowledgements}

The Tellus Project was financed by the Department of Enterprise, Trade and Investment (DETI), of Northern Ireland with retrospective contributions from the EUfunded 'Building Sustainable Prosperity' scheme of the Rural Development Programme. Thanks are due to all who took part in the sampling, preparation, analysis and quality control phases of the G-BASE and Tellus projects. This paper is published with the permission of the Executive Director, British Geological Survey. 


\section{References}

Anderson, T.B. 1962. The stratigraphy, sedimentology and structure of the Silurian rocks of the Ards Peninsula, County Down. Unpublished Ph.D. thesis, University of Liverpool.

Anderson, T.B. 2001. Structural interpretations of the Southern Uplands Terrane. Transactions of the Royal Society of Edinburgh: Earth Sciences, 91, 363-373.

Anderson, T.B. 2004. Southern Uplands - Down - Longford Terrane. In: Mitchell, W.I. (ed.). The Geology of Northern Ireland - Our Natural Foundation. Geological Survey of Northern Ireland, Belfast. Chapter 4, 41-60.

Anderson, T.B. \& Oliver, G.J.H. 1986. The Orlock Bridge Fault: a major Late Caledonian sinistral fault in the Southern Uplands terrane, British Isles. Transactions of the Royal Society of Edinburgh: Earth Sciences, 77, 203-222.

Arthurs, J.W \& Earls G. 2004. Minerals. In: Mitchell, W.I. (ed.). The Geology of Northern Ireland - Our Natural Foundation. Geological Survey of Northern Ireland, Belfast. Chapter 21, 255-272.

Barnes, R.P., Anderson, T.B. \& McCurry, J.A. 1987. Along-strike variation in the stratigraphical and structural profile of the Southern Uplands Central Belt in Galloway and Down. Journal of the Geological Society, London, 144, 807-816.

Barnes, R.P., Lintern, B.C. \& Stone, P. 1989. Timing and regional implications of deformation in the Southern Uplands of Scotland. Journal of the Geological Society, London, 146, 905-908.

Baron, M. and Parnell, J.; 2000. Multiple episodes of fluid flow in base-metal deposits from southwest Scotland and Northern Ireland: International Conference on Fluid Evolution, Migration and Interaction in Sedimentary basins and Orogenic Belts Journal of Geochemical Exploration, Vol. 69/70 - Geofluids III, p.143-148 
Beamish, D., Kimbell, G.S., Stone, P. and Anderson, T.B. in press/2010. Regional conductivity data used to reassess Lower Palaeozoic structure in the Northern Ireland sector of the Southern Uplands - Down-Longford terrane. Journal of the Geological Society, London.

Breward, N. 2003. Heavy-metal contaminated soils associated with drained fenland in Lancashire, UK, revealed by BGS Soil Geochemical survey. Applied Geochemistry 18, 1663-1670.

Breward, N. 2007. Arsenic and presumed resistate trace element geochemistry of the Lincolnshire (UK) sedimentary ironstones, revealed by a regional geochemical survey using soil, water and stream sediment sampling. Applied Geochemistry, 22 (2007) 1970-1993.

British Geological Survey. 1993. Regional geochemistry of southern Scotland and part of northern England. British Geological Survey, Keyworth, Nottingham.

Chapman, R J, Leake, R C, Moles, N R, Earls, G, Cooper, C, Harrington, K \& Berzins, R (2000) The application of microchemical analysis of alluvial gold grains to the understanding of complex local and regional gold mineralization: a case study in the Irish and Scottish Caledonides. Economic Geology 95, 1753-1773.

Flight, D.M.A., Christie, J.L., Lister, T.R., Simpson, P.R. \& Smith, B. 1995. Results of a pilot geochemical survey, Northern Ireland. Geological Survey of Northern Ireland Technical Report GSNI/95/6

Floyd, J.D. 1996. Lithostratigraphy of the Ordovician rocks in the Southern Uplands: Crawford Group, Moffat Shale Group, Leadhills Supergroup. Transactions of the Royal Society of Edinburgh: Earth Sciences, 86, 153-165.

Floyd, J.D. 2001. The Southern Uplands Terrane: a stratigraphical review. Transactions of the Royal Society of Edinburgh: Earth Sciences, 91, 349-362. 
Fordyce, F.M ., Brown, S.E., Ander, E.L., Rawlins, B.G., O’Donnell, K.E. Lister, T.R., Breward, N. \& Johnson, C.C. 2005. GSUE: Urban geochemical mapping in Great Britain Geochemistry: Exploration Environment Analysis, 5, 325-336.

Geological Survey of Northern Ireland. 1997. Northern Ireland. Solid Geology (Second Edition). 1:250 000. British Geological Survey, Keyworth, Nottingham.

Johnson, C. C. 2005. 2005 G-BASE Field Procedures Manual. British Geological Survey Internal Report, IR/05/097.

Johnson, C. C. and Breward, N. 2004. G-BASE: Geochemical Baseline Survey of the Environment. British Geological Survey Commissioned Report, CR/04/016N.

Johnson, C.C., Breward, N., Ander, E.L. \& Ault L. 2005. G-BASE: Baseline geochemical mapping of Great Britain and Northern Ireland. Geochemistry: Exploration Environment Analysis, 5, 347-358.

Hughes, R.A. 1995. The duration of Silurian graptolite zones. Geological Magazine, 132, 113-115.

Kelling, G., Davies, P. \& Holroyd, J. 1987. Style, scale and significance of sand bodies in the Northern and Central Belts, southwest Southern Uplands. Journal of the Geological Society, London, 144, 787-805.

Leggett, J.K., McKerrow, W.S. \& Eales, M.H. 1979. The Southern Uplands of Scotland: a Lower Palaeozoic accretionary prism. Journal of the Geological Society, London, 136, 755-770.

Meighan, I.G., Hamilton, M.A., Gamble, J.A., Ellam, R.M. and Cooper, M.R. 2003. The Caledonian Newry Igneous Complex, north-east Ireland: New U-Pb ages, a subsurface extension and magmatic epidote. Irish Journal of Earth Sciences Vol. 21 (2003), Abstracts of the 46th Irish Geological Research Meeting, Belfast, February 2003, p.156-157 
Moles, N. 2004. Dispersion of cerussite-rich tailings and plant uptake of heavy metals at historical lead mines near Newtownards, Northern Ireland. Transactions of the Institution of Mining and Metallurgy Section B Applied Earth Science Vol. 113 pt/no 1 (2004) p B21-B30

Moles, N R, O’Reilly, C, Parnell, J \& Rodgers, A (1997) Hydrothermal vein mineralization in the Lower Palaeozoic of Northern Ireland: Evidence for multiple fluid pulses. Extended abstract in Hendry, J P et al. (eds.) Geofluids II, Queen’s University of Belfast, 197-200.

Parnell, J (1995) Sulphide vein mineralisation in Northern Ireland: constraints on fluid sources. In Pasava, J, Kribek, B and Zak, K (eds) Mineral Deposits: From Their Origin to Their Environmental Impacts. Rotterdam, Balkema, 373-376.

Pattrick, R.A.D. \& Russell, M.J. 1989. Sulphur isotopic investigation of Lower Carboniferous vein deposits of the British Isles. Mineralium Deposita, 24, 148-153.

Peach, B.N. \& Horne, J. 1899. The Silurian rocks of Britain, 1: Scotland. Memoir of the Geological Survey of the United Kingdom. Geological Survey of the UK, London.

Phillips, E.R., Barnes, R.P., Boland, M.P. Fortey, N.J. \& McMillan, A.A. 1995. The Moniaive Shear Zone: a major zone of sinistral strike-slip deformation in the Southern Uplands of Scotland. Scottish Journal of Geology, 31, 139-149.

Rushton, A.W.A., Stone, P. \& Hughes, R.A. 1996. Biostratigraphical control of thrust models for the Southern Uplands of Scotland. Transactions of the Royal Society of Edinburgh: Earth Sciences, 86, 137-152.

Sharpe, E.N. 1970. An occurrence of pillow lavas in the Ordovician of County Down. Irish Naturalists Journal, 16, 299-301.

Stone, P. 1995. Geology of the Rhins of Galloway district. Memoir of the British Geological Survey, sheets 1 and 3 (Scotland). 
Stone, P. \& Merriman, R.J. 2004. Basin thermal history favours an accretionary origin for the Southern Uplands terrane, Scottish Caledonides. Journal of the Geological Society, London, 161, 829-836.

Stone, P., Green, P.M., Lintern, B.C., Simpson, P.R. \& Plant, J.A. 1993. Regional geochemical variation across the Iapetus Suture zone: tectonic implications. Scottish Journal of Geology, 29, 113-121.

Stone, P.; Green, P.M.; Lintern, B.C.; Plant, J.A.; Simpson, P.R \& Breward, N. 1991. Geochemistry characterizes provenance in southern Scotland : Geology Today, 7(5) 1991 p177-181

Stone, P., Green, P.M. \& Williams, T.M. 1997. Relationship of source and drainage geochemistry in the British paratectonic Caledonides: an exploratory regional assessment. Transactions of the Institution of Mining and Metallurgy, 106, B79-B84.

Stone, P., Plant, J.A., Mendum, J.R. \& Green, P. 1999. A regional geochemical assessment of some terrane relationships in the British Caledonides. Scottish Journal of Geology, 35, 145-156.

Stone, P., Breward, N. \& Merriman, R.J. 2003. Mineralogical controls on metal distribution in stream sediment derived from the Caledonides of the Scottish Southern Uplands and English Lake District. Mineralogical Magazine, 67, 325-338.

Stone, P., Breward, N., Merriman, R.J. \& Plant, J. A. 2004. Regional geochemistry of cryptic geology: variations in trace element distribution across the Southern Uplands terrane, Scotland. Applied Earth Science (Transactions of the Institution of Mining and Metallurgy B), 113, B43-B57.

Stone, P., Breward, N., Merriman, R.J. \& Barnes, R.P. 2006. The interpretation and application of regional geochemistry: lessons from the Paratectonic Caledonides. Scottish Journal of Geology, 42, 65-76. 
Vaughan, A. P. M. \& Johnston, J. D. 1992. Structural constraints on closure geometry across the Iapetus suture in eastern Ireland. Journal of the Geological Society, London, 149, 65-74. 